\title{
Antibacterial finishing of cotton fabric with clove oil microcapsules
}

\author{
Kalindri Verma and Meenu Srivastava
}

Received: 24.08.2020; Revised: 04.11.2020; Accepted: 24.11.2020

See end of the paper for authors' affiliations Kalindri Verma Department of Textiles and Apparel Designing, College of Community and Applied Science, Maharana Pratap University of Agriculture and Technology, Udaipur (Rajasthan) India Email : kalindri.verma88@gmail. com
ABSTRACT : The present study was conducted to develop a microencapsulated antibacterial finish using clove essential oil for cotton fabric. Microcapsules of clove essential oil (Syzygium fragranceticum) were developed with phase separation - complex coacervation technique using five concentrations of essential oil for application on cotton fabric. The finished cotton fabric was tested for SEM analysis and anti-bacterial finish using standard test methods. Findings of SEM analysis revealed that small spherical shape microcapsules in the treated samples were located at interstices between the fibres and on the fibre surface. The zone of inhibition was found maximum at concentration 5 of MCCL treated cotton fabric before wash with $12.5 \mathrm{~mm} \pm 1.5$ and $12.33 \mathrm{~mm} \pm 0.57$ (Mean and SD) against $S$. aureus and E. coli. MCCL oil treated cotton fabric showed the good wash durability against $S$. aureus as compared to E.coli. The antimicrobial property decreased with increasing number of wash cycles.

KEY WORDS: Antimicrobial, Finishing, Cotton, Clove, Oil, Microcapsule

- HOW TO CITE THIS PAPER : Verma, Kalindri and Srivastava, Meenu (2020). Antibacterial finishing of cotton fabric with clove oil microcapsules. Asian J. Home Sci., 15 (2) : 330-335, DOI: 10.15740/HAS/ AJHS/15.2/330-335. Copyright@ 2020: Hind Agri-Horticultural Society. 